MURRAY AND TRETTEL, INCORPORATED

DENNIS W. TRETTEL

\section{Certified Consulting Meteorologist}

Founded 1946, Micro/Operational Forecasting • Media • Air Quality/

Meteorological/PSD Monitoring/Studies • Forensic Research

- Dispersion Modeling • Nuclear Emergency Support

600 First Bank Drive, Suite A

Palatine, IL 60067

$847-963-9000$

FAX: 847-963-0245

E-mail:mt@weathercommand.com

\section{NORTH AMERICAN WEATHER \\ CONSULTANTS}

DON A. GRIFFITH, PRESIDENT

\section{Certified Consulting Meteorologist}

Weather Modification • Air Quality Surveys \& Field Studies • Applied

Research • Forensic Meteorology

8180 South Highland Dr., Suite B-2

Sandy, UT 84093
$801-942-9005$

FAX 801-942-9007

E-mail: nawc@nawcinc.com

\section{WEATHER RESEARCH CENTER} JOHN C. FREEMAN WEATHER MUSEUM JILL F. HASLING, DIRECTOR

\section{Certified Consulting Meteorologist}

Worldwide Weather \& Oceanographic Forecasting • Climatology

- Training • Expert Testimony • Research in Meteorology \&

Oceanography $\bullet$ Wave Spectra $\bullet$ Software Development $\bullet$ The WRC

Weather Museum
5104 Caroline St

Houston, TX 77004

Website: www.wxresearch.com
Phone: 713-529-3076

Fax: 713-528-3538 E-mail:WRC@wxresearch.org
TRC ENVIRONMENTAL CORP.

GALE F. HOFFNAGLE

DOUGLAS R. MURRAY

ALFRED M. KLAUSMANN
PIETRO A. CATIZONE JOSEPH S. SCIRE LLOYD L. SCHULMAN

\section{Certified Consulting Meteorologists}

Environmental Consulting \& Research • Applied Meteorology • Air Quality and Meteorological Monitoring $\bullet$ Diffusion Modeling $\bullet$ Tracer Studies • Air Toxics Monitoring • Expert Testimony

1-800-TRC-5601

Offices in major industrial centers throughout the United States

\section{ATMOSPHERIC SYSTEMS CORPORATION}

KENNETH H. UNDERWOOD, Ph.D.

\section{Certified Consulting Meteorologist}

Sodar Systems/Boundary Layer Studies • Meteorological Instruments and Systems/Meteorological Analysis • Wind Engineering Studies/Micrometeorology/Mixing Depth Studies - Acoustic Propagation/Noise Studies/Expert Testimony 24900 Anza Drive, Unit D

phone: 661-294-9621

Santa Clarita, CA 91355 fax: 661-294-9667 E-mail: ken@minisodar.com
MCVEHIL-MONNETT ASSOCIATES, INC. GEORGE E. McVEHIL, Ph.D. KENDALL C NECKER

\section{Certified Consulting Meteorologists} Modeling • Air Toxics • Meteorological Analysis •Industrial Meteorology $\bullet$ Litigation Support $\bullet$ Expert Testimony
Air Quality Analysis and Monitoring $\bullet$ Permitting $\bullet$ Dispersion

\section{APPLIED METEOROLOGY, INC.} JOHN W. HATHORN

\section{Certified Consulting Meteorologist}

Meteorological Consulting \& Analysis • Air Quality Modeling \& Monitoring • Site Selection \& Permitting • Environmental Data Acquisition Systems \& Network with Remote-Control

9110 Weymouth Dr.

Houston, TX 77031-3034
SIMPSON WEATHER ASSOCIATES, INC.

M. GARSTANG, Ph.D.

R.H. SIMPSON, Ph.D. (retired)

G. D. EMMITT, Ph.D.

\section{Certified Consulting Meteorologists}

Environmental Risk Assessment • Air Quality Modeling/Monitoring - Instrumentation Development/Deployment

- Lidar simulation/application

809 E. Jefferson St.

434-979-3571

Charlottesville, VA 22902

FAX: 434-979-5599

\section{INTERNATIONAL CENTER FOR THE SOLUTION OF ENVIRONMENTAL PROBLEMS \\ JOSEPH L. GOLDMAN, PH.D., TECHNICAL DIRECTOR}

\section{Certified Consulting Meteorologist}

Broad Scope Assessments by Interdisciplinary Experts Worldwide - Specialize in Mesometeorological Variations - Climate Change - Problems Posed, Solutions Implemented \& Demonstrated 509 North 7th Street

Alpine, TX 79830

$$
\text { 432-837-0157 }
$$

E-mail: icsep@airmail.net

\section{CLIMATOLOGICAL CONSULTING CORPORATION}

LEE E. BRANSCOME, Ph.D., President DOUGLAS A. STEWART, Ph.D.

\section{Certified Consulting Meteorologists}

Forensic Meteorology • Weather Risk Analysis

- Climate Studies - Computer Modeling of the Atmosphere

7338 155th Place North

Palm Beach Gardens, FL 33418

www.ccc-weather.com

$561-744-4889$

FAX: $561-744-5098$

Ibranscome@ccc-weather.com

Certified Consulting Meteorologist: The certification program of theAmerican Meteorological Society is aimed at fostering the establishment and maintenance of a high level of professional competency, and mature and ethical counsel, in the field of consulting meteorology. Requirements of knowledge, experience, and character are determined by a five-person board. Objectives of the program and application procedures are described in full detail in the August 2001 (Pp. 1689-1694). 


\section{AEROCOMP}

JOSEPH A. CATALANO

\section{Certified Consulting Meteorologist}

Expert Testimony • Climatological Analysis • Industrial Meteorology \& Air Impact $\bullet$ Atmospheric Modeling $\bullet$ Wind \& Ice Loading $\bullet$ Data Management Software \& Services

714-964-3672

P.O. Box 26109

Santa Ana, CA 92799-6109
FAX: 714-964-1357

E-mail:ccm299@aerocomp.com
WILKENS WEATHER TECHNOLOGIES, L. P. RICHARD B. WILKENS, PRESIDENT

\section{Certified Consulting Meteorologist}

Specialists in Offshore, Energy, and Industrial Forecasting Worldwide - Hindcast and Climatological Studies • Custom Weather Graphics and Information

2925 Briarpark, 7th Floor $713-430-7100$ Houston, TX 77042-3715 (Toll Free) 800-503-5811

E-mail: wwt@ wilkensweather.com Web site: http://www.wilkensweather.com

\section{FREESE-NOTIS WEATHER, INC.} HARVEY FREESE, M.S.

\section{Certified Consulting Meteorologists}

Worldwide Forecasts for: Agricultural \& Energy Commodities - Construction - Media • Highway Departments • Forensic Meteorology $\bullet$ Internet Service Provider $\bullet$ Weather Products through Internet

2411 Grand Ave. Des Moines, IA 50312
Phone: 515-282-9310

Fax: 515-282-6832 E-mail: hfreese@ weather.net Internet: www.weather.net/fn/ams

WEATHERDATA SERVICES, INC.

\section{an AccuWeather Company}

MICHAEL R. SMITH, CEO/FOUNDER

STEPHEN PRYOR, MANAGER RESEARCH METEOROLOGY

\section{Certified Consulting Meteorologists}

- Premier Meteorological Consultants Serving All Industries

- Forensic Services • Forecast Services • Expert Testimony

- Exclusive Technology • Extensive Database - Comprehensive Studies

245 North Waco Ste. 310

Wichita, KS 67202

www.weatherdata.com
Phone: 316-265-9127 sales@ weatherdata.com

\section{ACCU WEATHER, INC.}

ELLIOT ABRAMS, SENIOR VICE PRESIDENT

STEPHAN M. WISTAR, SENIOR METEOROLOGIST

\section{Certified Consulting Meteorologists}

Meteorological Consultants Serving Industry, Government and the Media • Forensic Services • Forecast Services • Expert Testimony - Complete Database - Applied Information Technologies

385 Science Park Road State College, PA 16803 www.AccuWeather.com
814-235-8626 Fax: 814-235-8769 E-mail: forensics@accuweather.com

\section{AIR SCIENCE CONSULTANTS, INC.}

SKYWATCH WEATHER CENTER ${ }^{\circledR}$

ANTHONY J. SADAR, M.S.

\section{Certified Consulting Meteorologist}

Forecasting Services for Industry, Government and News Media• Air Quality Modeling • Impact and Climatological Studies • Forensic Meteorology • Environmental Assessments

347 Prestley Rd.

Bridgeville, PA 15017

$412-221-6000$ FAX: $412-221-3160$

E-mail: airsci@skywatchweather.com

\section{METEOROLOGICAL EVALUATION SERVICES, CO. INC. (MES) \\ PATRICK T. BRENNAN, PRESIDENT}

\section{Certified Consulting Meteorologist}

Air-Quality Consulting $\bullet$ Expert Testimony $\bullet$ Industrial Meteorology - Nuclear Licensing Studies • Weather Investigations for Legal and Insurance Firms

165 Broadway

Amityville, NY $11701 \quad$ E-mail: info@mesamity.com

\section{TRINITY CONSULTANTS}

GEORGE J. SCHEWE, PRINCIPAL CONSULTANT ANTHONY J. SCHROEDER, SENIOR CONSULTANT

\section{Certified Consulting Meteorologists}

Air Quality Consulting $\bullet$ Regulatory Modeling $\bullet$ Meteorology/Climatology - Dispersion Modeling Courses Worldwide - BREEZE® Dispersion Modeling Software • Litigation Support

Covington, $\mathrm{KY}$ 859-341-8100

\section{gschewe@trinityconsultants.com} tschroeder@trinityconsultants.com

\section{SKY FIRE PRODUCTIONS, INC.}

WeatherVideoHD.tv

WALTER A. LYONS, Ph.D., President

\section{Certified Consulting Meteorologist}

Royalty Free Time Lapse Weather Footage (HD and SD) for producers and educators • Post-Production Services • Informal Science Education Programs • Online Educational DVD Sales
46050 Weld County Road 13

Ft. Collins, CO 80524

Phone: 970-416-8851
www.Sky-Fire.tv www. WeatherVideoHD.tv Fax: $970-482-8627$

\section{EDWARD E. HINDMAN (Ward), Ph.D.}

\section{Certified Consulting Meteorologist}

Specializing in Meteorological Analyses, Education, and Expert Testimony 


\section{ANTHONY (ANDY) JOHNSON}

\section{Certified Consulting Meteorologist \\ Expert Testimony $\bullet$ Weather Investigations for Legal and Insurance \\ Firms • Forensic Meteorology • Consultant since 1979}

3912 West Dale Ave

Tampa, FL 33609

E-mail: AndyCCM@aol.com
Phone: 813-870-9696 $813-878-2929$

FAX: 813-872-7202
METEOROLOGICAL SOLUTIONS INC. GEORGE W. WILKERSON

DAN A. RISCH

\section{Certified Consulting Meteorologists}

Air Quality Modeling \& Development • Permitting • Ambient Monitoring • Calibrations \& Audits • Tracer Studies • Forecasting • Custom Software $\bullet$ Applied Meteorology $\bullet$ CALPUFF Modeling $\bullet$ Field Studies

2257 South 1100 East, Suite 203

Salt Lake City, UT 84106

$801-474-3826$

Website: www.metsolution.com

\section{HOW THE WEATHERWORKS}

H. MICHAEL MOGIL, PRESIDENT

\section{Certified Consulting Meteorologist}

Specializing in forensic meteorology, expert testimony, and data analysis for legal and insurance matters; also educational design and weather-based training and educational courses, science writing and weather photography.

1104 6th Street South Naples, FL 34102 www.weatherworks.com hmmogil@ weatherworks.com

Phone: 239-592-6636 Cell: $240-426-2900$ Fax: 202-742-2806
AIR WEATHER \& SEA CONDITIONS, INC. JAY ROSENTHAL, PRESIDENT

\section{Certified Consulting Meteorologist}

Expert testimony and data analysis for legal and insurance matters - Accident weather reconstruction - Satellite Interpretation • Air Pollution Transport • Excellent Client References • Emergency Response

P. O. Box 512

Pacific Palisades, CA 90272

Phone: 818-645-8632 $310-454-7549$

FAX: 310-454-7569

Website: www.weatherman.org

\section{CARL LARRY PEABODY}

\section{Certified Consulting Meteorologist}

Expert Testimony; Forensic Meteorology; Climatological Studies; Meteorological and Oceanographic Analysis; Legal and Insurance Weather Investigation; Outdoor Events Weather Observations and Forecasts; Freelance Writing-Magazine Weather Articles

11611 Caprock

San Antonio, TX 78230-2102
210-558-3906; fax: 210-558-6166 e-mail: Ipeabody@satx.rr.com

\section{INTEGRATED ENVIRONMENTAL DATA} KATHLEEN E. MOORE, PH.D.

\section{Certified Consulting Meteorologist}

Renewable Energy • Forest \& Agricultural Meteorology • Certified Forester • QAVQC Audits • Boundary Layer Studies • Sodar \& Radar Profiling Analyses • Remote Sensing Studies

255 Fuller Rd.

Albany, NY 12203

kemoore@iedat.com www.iedat.com (518) 956-7030

\section{MAYACAMAS WEATHER CONSULTANTS}

JOHN P. MONTEVERDI, Ph.D., DIRECTOR

\section{Certified Consulting Meteorologist}

Forensic Meteorology • Climate Studies • Litigation Support • Expert Testimony $\bullet$ Operational Forecasts and Nowcasts
4425 View Street

Oakland, CA 94611
415-882-9898

Fax: $510-653-4320$
E-mail: montever@comcast.net Website: www.mayacamaswx.com

WEATHER DECISION TECHNOLOGIES, INC. RICHARD L. CARPENTER, JR., Ph.D.

J. WILLIAM CONWAY

\section{Certified Consulting Meteorologists}

Radar Meteorology • Severe Weather Nowcasting and Analysis • Mesoscale and Microscale Numerical Modeling • Aviation Weather • Forensic Meteorology • Expert Testimony

3100 Monitor Ave., Suite 280

Norman, OK 73072

405-579-7675

www.wdtinc.com www.hailtrax.com info@wdtinc.com

\section{ATMOSPHERIC INFORMATION \\ SERVICES}

JEFFREY M. FREEDMAN, ESQ., Ph.D.

\section{Certified Consulting Meteorologist}

Applied Meteorological Research $\bullet$ Field Project Design and

Management • Climatological Analysis • Environmental Assessments

- Hydrometeorological Studies • Boundary Layer Studies • Forensic

Investigations $\bullet$ Expert Testimony

255 Fuller Road

Suite 296

Albany, NY 12203
Phone: $518-437-8712$

E-mail: jmf@atmosinfo.com Web: www.atmosinfo.com

\section{AECOM}

WILLIAM GROOT

\section{Certified Consulting Meteorologists}

Air Quality Modeling \& Development • Evaluation • Permitting • Data Analysis • Air Toxics • Acid Deposition • Ozone • Complex Terrain - CALPUFF Modeling • Expert Testimony

Certified Consulting Meteorologist: The certification program of the American Meteorological Society is aimed at fostering the establishment and maintenance of a high level of professional competency, and mature and ethical counsel, in the field of consulting meteorology. Requirements of knowledge, experience, and character are determined by a five-person board. Objectives of the program and application procedures are described in full detail in the August 200। (pp. 1689-1694). 


\section{PROFESSIONAL DIRECTORY}

SPACE RESERVED FOR CERTIFIED CONSULTING METEOROLOGISTS

WALSH ENVIRONMENTAL, LLC

ARTHUR P. MIZZI, Ph.D., J.D.

\section{Certified Consulting Meteorologist}

Atmospheric/Air Pollution Modeling and Analysis • Regulatory

Compliance Advising $\bullet$ Wind Energy Resource Assessments • Climate

Change Impact Assessment and Downscaling Studies • Environmental

Consulting and Permitting • Expert Testimony

Phone: $303-903-5544$

4888 Pearl East Circle, Suite 108

E-mail: amizzi@walshenv.com Boulder, CO 80301

\section{ERM}

DAVID H. MINOTT

\section{Certified Consulting Meteorologist}

Air Dispersion Modeling • Air Toxics • Risk Assessment

- Environmental Permitting and Consulting • Global Warming

Offices Throughout the U.S. and Worldwide

$617-646-7802$ www.erm.com

\section{CLIMATE \& ATMOSPHERIC RESEARCH}

\section{ASSOCIATES, LLC (CARA)}

THOMAS W. TESCHE, Ph.D.

\section{Certified Consulting Meteorologist}

Regional Climate \& Chemical Transport Modeling $\bullet$ 8-hr Ozone \& PM2.5 SIP Modeling • MM5 \& WRF Mesoscale Modeling • CAMx,

CMAQ, GEOS-Chem Applications • Emissions Inventory Development

- Snow and Ice Research • Litigation \& Expert Testimony

3479 Reeves Drive

twt@iac.net

Ft. Wright, KY 41017

\section{CLIMATE PHYSICS, LLC}

EDWIN X BERRY, Ph.D.

\section{Certified Consulting Meteorologist}

In a world of climate delusions

We bring you valid conclusions

439 Grand Ave., \#147

Bigfork, MT 59911

406-471-1464

ed@climatephysics.com 
GEOMET TECHNOLOGIES, INC.

MARK J. STUNDER

Environmental Expert Systems, Artificial Intelligence • Air Pollution Analysis, Modeling \& Monitoring • Weather Risk Management, Climatological Studies $\bullet$ Research and Operations

20251 Century Blvd

Germantown, MD 20874
ACCU WEATHER, INC.

JOEL N. MYERS, Ph.D., PRESIDENT

BARRY LEE MYERS, J.D., CHIEF EXECUTIVE OFFICER

JOSEPH P. SOBEL, Ph.D., SENIOR VICE PRESIDENT

Accurate, Custom Weather Forecasts and Warnings • Media Content • Climatological, Forensic and Consulting Services • Complete Weather Systems and Solutions • Over 45 Years of Quality Service
385 Science Park Road State College, PA 16803 www.AccuWeather.com
Phone: 814-237-0309 Fax: 814-235-8509

E-mail: info@AccuWeather.com

\section{Empowering You To Be The Best ${ }^{\mathrm{Tm}}$}

FLEETWEATHER, INC.

Since 1969

TORE H. JAKOBSEN, M.S., CO-OWNER

Forecasts for Weather-Sensitive Industry • Past Weather Research \& Expert Testimony • Global Ship-Guidance \& Surveillance • Weathercasting $\bullet$ Automated Weather Databases \& Delivery Systems

The Fleetweather Building, 2566 Route 52 Hopewell Jct., NY 12533
FOX WEATHER

ALAN FOX, DIRECTOR

Satellite Analyses • Remote Sensing Studies • Site Forecasts • Extended Outlooks • Quantitative Precipitation Forecasts, Product Delivery via Internet

609 14th Street, Suite A Fortuna, CA 95540

$805-985-8743$ Fax: 707-725-9380

\section{CONNECTICUT WEATHER CENTER, INC.} WILLIAM JACQUEMIN, CHIEF METEOROLOGIST, PRESIDENT

PROFESSIONAL SERVICES: Weather Forecasting for Media, Utilities, Industry, Ski Areas, Government, Educational Svcs, and Insurance/Lawyer Reports

18 Woodside Avenue Danbury, CT 06810-7123

Phone: 203-730-CTWX (2899)

Web site: www.ctweather.com E-mail: weatherlab@ctweather.com
Fax: 203-730-CTFX (2839)

\section{METEO CONSULT}

HARRY A. OTTEN, MANAGING DIRECTOR

MAARTEN NOORT, DIRECTOR

Worldwide Forecasting • Media • Marine (legally recognized in Dutch law) • Leading Experts in Winter Road Maintenance • Agriculture •

Data $\bullet$ Software $\bullet$ Research and Consulting $\bullet$ Lightning Data

P.O. Box 617

6700 AP Wageningen

The Netherlands
31317399800 Fax: 31317423164

\section{R. M. YOUNG COMPANY}

\section{Meteorological Instruments since 1964}

Sensors to Measure: Wind Speed •Wind Direction • Peak Gusts • Temperature $\bullet$ Pressure $\bullet$ Relative Humidity $\bullet$ Precipitation

2801 Aero-Park Drive

231-946-3980

Traverse City, Michigan 49686
WEATHERBANK, INC.

STEVEN A. ROOT, CCM

President/CEO

MICHAEL R. ROOT Executive Vice President/CFO

Operational Forecasting • Broadcast Services • Forensic Studies • Real-Time and Historical Weather Databases • Satellite Transmission Network • Weather/Air Quality Monitoring and Climatological Studies

\section{More Than 35 Years of Providing Quality Service}

1015 Waterwood Parkway, Suite J

Edmond, Oklahoma 73034

405-359-0773

Fax: 405-341-0115 www.weatherbank.com
SONALYSTS, INC.

RIP COLEMAN

KATHY LUCAS

wXstation ${ }^{\sqrt{ }}$ Weather Display and Analysis Software

Integrated display of worldwide satellite imagery, radar, lightning, GRIB aircraft positions, and text weather from multiple sources. Software development, systems integration, training, installation, and maintenance.

P.O. Box 280

Waterford, CT 06385
215 Parkway North
Fax: $860-447-8883$

Web: www.sonalysts.com
Phone: $860-442-4355$
PATRICK KELLY JOSH ROVERO
For professional card rates, please apply to:

Executive Director, American Meteorological Society, 45 Beacon St., Boston, MA 02108-3693
Phone: 860-450-1717

P. O. Box 605

Mansfield Center, CT 06250-0605

E-mail: LyleL@scieng.com
Fax: 860-450-1707 Web site: www.scieng.com 


\section{PROFESSIONAL DIRECTORY}

\section{SPACE RESERVED FOR MEMBERS}

\section{WEATHER CENTRAL INC.}

Weather Central empowers broadcasters to attract and connect with viewers through highly local forecasts and severe weather coverage. Our solutions advance the business objectives of the broadcast, online, and print industries. Our clients dominate their markets with the best technology available.

5725 Tokay Boulevard

Madison, WI 53719

Phone: 608-274-5789

Fax: 608-278-2746

\section{A. H. GLENN AND ASSOCIATES SERVICES}

CLAUDE V. PALLISTER III

Consultants in Meteorology and Oceanography since 1946

New Orleans Lakefront Airport

P. O. Box 26337

504-241-2222

New Orleans, LA 70186

\section{J GILE, INC.}

\section{METEOROLOGICAL \& AIR QUALITY CONSULTING}

Meteorological \& Air Quality Monitoring • Turnkey Program

Development $\bullet$ Worldwide Services $\bullet$ Environmental Auditing •

Quality Assurance Program Development $\bullet$ Customized Data

Acquisition \& Software Programming $\bullet$ Data Management \&

Reporting

P. O. Box 706

Kennebunkport, ME 04046

Internet: www.djgile.com
Phone: 207-967-5286

Fax: 207-967-4107 E-mail: solutions@djgile.com
ALTOSTRATUS, INC.

HAIDER TAHA, Ph.D., PRESIDENT

Meteorological modeling $\bullet$ Photochemical and dispersion modeling

- Regulatory modeling for ozone and PM • Fine-resolution urban

meteorological modeling $\bullet$ Aerometric data analysis $\bullet$ Weather

derivatives and applied meteorology

940 Toulouse Way

Martinez, CA 94553

Ph: 925-228-1573

URL: www. altostratus.com

E-mail: haider@altostratus.com 


\section{TABLES OF CONTENTS FOR AMS JOURNALS}

\section{Monthly Weather Review}

Vol. 137, No. 5, May 2009

\section{ARTICLES}

Bow Echo Mesovortices. Part I: Processes That Influence Their Damaging Potential

Bow Echo Mesovortices. Part II: Their Genesis

Nolan T. AtKins and Michael St. Laurent

*The Overamplification of Gravity Waves in Numerical Solutions to Flow over Topography

Patrick A. Reinecke and Dale Durran

Variability of Updraft and Downdraft Characteristics in a Large Parameter Space Study of Convective Storms

Cody Kirkpatrick, Eugene W. McCaul Jr., and Charles Cohen

Impact of Data Assimilation on Forecasting Convection over the United Kingdom Using a High-

Resolution Version of the Met Office Unified Model

Mark Dixon, Zhihong Li, Humphrey Lean, Nigel Roberts, and Sue Ballard

Objective Classification of Precipitating Convective Regimes Using a Weather Radar in Darwin,

Australia

Simon Caine, Christian Jakob, Steven Siems, and Peter May

The Tropical Madden-Julian Oscillation and the Global Wind Oscillation.....

Klaus Weickmann and Edward Berry

+Impact of Satellite-Derived Rapid-Scan Wind Observations on Numerical Model Forecasts of

Hurricane Katrina.

.rolf H. Langland, Christopher Velden, Patricia M. Pauley, and Howard Berger

${ }^{+}$A Method for Identifying the Sensitive Areas in Targeted Observations for Tropical Cyclone Prediction Conditional Nonlinear Optimal Perturbation.

Mu Mu, Feifan Zhou, and Hongli Wang

Sampling Errors in Ensemble Kalman Filtering. Part II: Application to a Barotropic Model

William Sacher and Peter Bartello

The Multiensemble Approach: The NAEFS Example Guillem Candille

Sensitivity Study of Regional Climate Model Simulations to Large-Scale Nudging Parameters

Adelina Alexandru, Ramon de Elia, René Laprise, Leo Separovic, and Sébastien Biner

An Ensemble-Based Four-Dimensional Variational Data Assimilation Scheme. Part II: Observing System Simulation Experiments with Advanced Research WRF (ARW)

. Chengsi LiU, Qingnong XiaO, and Bin Wang

$1497-1513$

$1514-1532$

$1533-1549$

$1550-1561$

$1562-1584$

$1585-1600$

$1601-1614$

$1615-1622$

$1623-1640$

$1641-1656$

$1657-1667$

$1668-1688$

$1689-1706$

\section{NOTES AND CORRESPONDENCE}

Adjoint Estimation of the Variation in Model Functional Output due to the Assimilation of Data

Dacian N. Daescu and Ricardo Todling

On the Reliability and Calibration of Ensemble Forecasts

Christine Johnson and Neill Bowler

$1707-1719$

$1720-1723$

*Special Collection: Terrain-Induced Rotor Experiment (T-REX)

+Special Collection: Targeted Observation, Data Assimilation, and Tropical Cyclone Predictability 


\title{
TABLES OF CONTENTS FOR AMS JOURNALS
}

\section{Journal of the Atmospheric Sciences}

\author{
Vol. 66, No. 5, May 2009
}

\section{ARTICLES}

Testing Lagrangian Theories of Internal Wave Spectra. Part I: Varying the Amplitude and Wavenumbers G. P. KLAASSEN

$1077-1100$

Testing Lagrangian Theories of Internal Wave Spectra. Part II: Varying the Number of Waves G. P. KLAASSEN

Gravity Wave Instability Dynamics at High Reynolds Numbers. Part I: Wave Field Evolution at Large Amplitudes and High Frequencies.

David C. Fritts, Ling Wang, Joe Werne, Tom Lund, and Kam Wan

$1126-1148$

Gravity Wave Instability Dynamics at High Reynolds Numbers. Part II: Turbulence Evolution, Structure, and Anisotropy

David C. Fritts, Ling Wang, Joe Werne, Tom Lund, and Kam Wan

Average Predictability Time. Part I: Theory

Timothy DelSole and Michael K. Tippett

Average Predictability Time. Part II: Seamless Diagnoses of Predictability on Multiple Time Scales

Timothy DelSole and Michael K. Tippett

${ }^{*}$ Lee-Wave Resonances over Double Bell-Shaped Obstacles

VANDA GRUbišić and IVANa StIPERSKi

${ }^{\star}$ Observations and Numerical Simulations of Subrotor Vortices during T-REX

James D. Doyle, Vanda Grubišić, William O. J. Brown, Stephan F. J. De Wekker, Andreas Dörnbrack, Qingfang Jiang, Shane D. Mayor, and Martin Weissmann

YUQING WANG

Large-Eddy Simulation of Moist Convection during a Cold Air Outbreak over the Gulf Stream .....

ERic D. SKyllingstad and James B. Edson

${ }^{+}$Generation and Propagation of Inertia-Gravity Waves from Vortex Dipoles and Jets

Shuguang Wang, Fuging Zhang, and Chris SNyder

+Spontaneous Imbalance and Hybrid Vortex-Gravity Structures

Michael E. MCINTYRe

A Climatology of the Gravest Waves in the Equatorial Lower and Middle Stratosphere: Method and Results for the ERA-40 Re-Analysis and the LMDz GCM

. François Lott, Jayanarayanan Kuttippurath, and François Vial

The Role of Eddies in Driving the Tropospheric Response to Stratospheric Heating Perturbations Isla R. Simpson, Michael Blackburn, and Joanna D. Haigh

Zonal Flow Regime Changes in a GCM and in a Simple Quasigeostrophic Model: The Role of Stratospheric Dynamics

Isabella Bordi, Klaus Fraedrich, Michael Ghil, and Alfonso Sutera

Predictability of Rotating Stratified Turbulence

K. NGan, P. Bartello, and D. N. Straub

Two Types of Baroclinic Life Cycles during the Southern Hemisphere Summer.....

Woosok Moon and Steven B. Feldstein

Global Circulation in an Axially Symmetric Shallow Water Model Forced by Equinoctial Differential Heating . Ori Adam and Nathan Paldor

Consistent Scale Interaction of Gravity Waves in the Doppler Spread Parameterization...

ERICH BEcker and Charles McLandress

The Influence of Entrainment and Mixing Assumption on Aerosol-Cloud Interactions in Marine Stratocumulus 